\section{MAGNET SYSTEMS FOR THE INTERNATIONAL THERMONUCLEAR EXPERIMENTAL REACTOR*}

\author{
C.D. Henning and J.R. Miller \\ Lawrence Livermore National Laboratory \\ University of California \\ Livermore, Californin 94550
}

UCRL--98728

DE89 001725

\section{Introduction}

The definition phase for the Intemational Themonuclear Experimental Resctor (ITER) ha been nearly completed, thu beginning a threc-year deaign efiort by tcams from the European Community (EC), Japan, U.S., and USSR. Preliminary parameters for the au. perconducting maznet system have been established to guide more detailed design work. Radiation tolerance of the unperconductors and insulators has been important lecause it sets requirements for the neutron-shield dimension and senvitively influences fesctor uize. Mejor levelo of mecharical otress sppear in the structural cases of the inbourd legs of the toroidal-field (TF) coils. The winding pack. of the TF coils include significant fraction of steel that provide sup. port against in-plane separating loads, but they offer little oupport gainst out-of-plane losds unless shear-bonding of the conductors can be maintained. Heat removal from nuclens and ac losds has not limited the fundamentai deaign, but it has nonnegligible economic consequences.

\section{Guidance to Design}

An ITER Specialists Meeting was convened May 9-13, 1988, to gather data and prepare for the ITER magnet design. Data from existing superconducting tokanak magnet systems were rcviewed to guide future design efforts. Table I liats the recent performance levels achieved. The Large Coil Task (LCT), T-15, and Tore-Supra are recent examples of superconducting tokamal magnet design. The designations $G E, G D, J A, C H, E U$, and $W H$ refer to the General Electric, Generd Dynamics, Japanese, Swiss, European, and Westinghouse large coils, respectively. Each used a different method of coil contruction, and all worked. However, becuuse field levels in ITER will be extended from 9 to $12 \mathrm{~T}$ ar higher, fored-flow niobjum-tin conductors are preferred. The achievable current density in niobjum. tin superconductorn was reviewed. The data in Fig. I can be adequately represented by the following detign formula for niobjum-tin performance with zero intrinsic strain:

$$
\begin{aligned}
J_{\mathrm{cm}}(B, T) & =J_{c a m}\left[1-\frac{T}{T_{\mathrm{cm}}(B)}\right], \\
\tau_{\mathrm{cm}}(B) & =T_{\mathrm{com}}\left(1-\frac{B}{B_{\mathrm{c} 20 m}}\right), \\
J_{c 0 m m}(B) & =\frac{\left.[11)\left(1-B / B_{\mathrm{c} 30 m}\right)\right]^{2}}{B^{1 / 2}}, \\
T_{\mathrm{com}} & =18 \mathrm{~K}, \\
B_{c 20 m} & =27.8 \mathrm{~T},
\end{aligned}
$$

where $J$ is the current density in $\mathbf{A} / \mathrm{mm}^{2}$ over the non-copper fraction of the conductor, $B$ is magnetic field, and $T$ is temperature. The subscript c refers to the critical value; the subscript 0 on $T_{c}$ refers to zero fiedd; the subscript 0 on $J_{c}$ and $B_{c 2}$ refers to zero temperature; and the subseript $m$ refers to the maximum value of that paraneter (i.e., st zero intringic strain). The curves in Fig. 1, from a survey by M. Sueuaga (private communication, July 1985), show eritica

\footnotetext{
"Work periormed undet the aupices of the U.S. Department of Energy by Lavrence Livermore Nationnl Labortary uader Contract W-740s-Eng-48.
}

current for wires with various compositions and manufacturing processes. The individual points represent ismples taken from a large mount of conductor purchased by LLNL.

Severa conductor aystems opplicable to ITER ha" been atud. ied and developed. Aithough the configurations of thit conductors are varied to accommodate atructural and itabillty c. Iderations, there is general apreement on the levels of current dens. y that can be shieved with reasonable development, In the oupercunducting (non-copper) fraction of the conductor, sbout $800 \mathrm{~A} / \mathrm{mm}^{2}$ at 12 $\mathrm{T}$ and $4.2 \mathrm{~K}$ is considered reasonable. Also, otructurn mierials could be devigned to two-thirds of yicld atress or half of the itimate tress with a resulting value up to $800 \mathrm{MPs}$. Good advances lave been made in unch material properties in recent yeurs, particularly in Japan, so that reliable cryogenic fabrications are postible. Toble II lists some of thr more advanced alloy, from Japan and the USSR that are useful for the primary magnet atructure. Ta! + III lists alloys for a niobium-tin conductor conduit that must recej $;$, the reaction temperature heat treatment.

There ha been considerable disagreement about radiation : 25ance of insulators that will receive dose from $5 \times 10^{8}$ to $10^{10}$, . Some information exists on glass epoxies from compresuion and ht. Ural teata; leas information exista for polyimides (most tests have been on mixtures of epories and polyimides-not pure polyimides). No information exists on theur atress effects at doses ranging from $10^{\circ}$ to $10^{10} \mathrm{rad}$. The results generally show decreases in utrengthe of $30-$ $60 \%$ ve unirradiated values witb dosel apprasching $10^{10}$ rads. With on optimization of the epoxy revins and the glous fbers, come date indicate that epoxies could be ured up to $10^{10}$ rads. In particular, the date in Fig. 2, from a 1985 CERN report [1], show that certain epoxy revins can withetand close to $10^{10}$ radi and retsin thes strength. Cleaning the fibergless mat by heating to $400^{\circ} \mathrm{C}$ helpo renove binders and impurities that cause degradation during iradition.

Regarding superconductors, ir adiation experinents uning $14 \mathrm{MeV}$ neutrons have been conducted on conmercially avilable materials at room temperature and at $4.6 \mathrm{~K}$ with tests at $14 \mathrm{~T}$ (see Fig. 3 ) $[2,3]$. Neutron dover up to $1.4 \times 10^{22} \mathrm{n} / \mathrm{m}^{2} \mathrm{at} 4.6 \mathrm{~K}$ and $2.6 \times 10^{23} \mathrm{n} / \mathrm{m}^{2}$ at room temperature were applied. The rerulta abow no degradation up to $2.5 \times 10^{22} \mathrm{n} / \mathrm{m}^{2}$. Critical current denvities (non-copper) ranged from 250 to $500 \mathrm{~A} / \mathrm{mm}^{2}$. Because the actual geutron energy spectrum in the ITER magnets will be much rofter than $814-\mathrm{MeV}$ snurce, the expected neutron dose in the magnet at which no degradation is expected is larger than $2.5 \times 10^{22} \mathrm{n} / \mathrm{m}^{2}$ (approaching $10^{23} \mathrm{n} / \mathrm{m}^{2}$ ); the actual dose will depend on the design of the inner ahield and magret.

\section{Initia] Engineering Design}

Although the ITER definition phase is not complete, sn initis engineering design was studied to assess the practicality of a 20-MA plasma current. Parameter for this example are lited in Table IV.

TF and poloidal field (PF) coils are being designed by each par. ticipant for comparion. Also, stress in the conductors, cases, and insulators is being evaluated to verify that the design envelope is credible. Eddy current losies could become iraportant to the detailed design aince the coils must withstand disruption conditions of $38 \mathrm{~T} / \mathrm{s}$ at the inboard leg with the possibility of a continuous $0.3 \mathrm{~Hz}$ cycling of the PF coli to distribute the divertor heat flux. 
Table L: Field and current density (conductor - He) reached

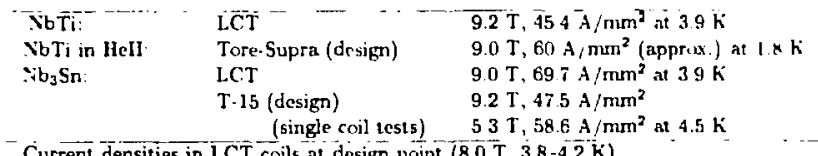

$\begin{array}{rrrrrrr}\text { GE } & \text { GD } & \text { JA } & \text { Cl } & \text { EC } & \text { WU } & \\ -25.0 & 28.2 & 26.1 & 38.0 & 42.9 & 64.6 & \text { (conductor + He) } \\ 15.7 & 15.3 & 16.0 & 17.9 & 16.3 & 17.6 & \text { (overnll) }\end{array}$

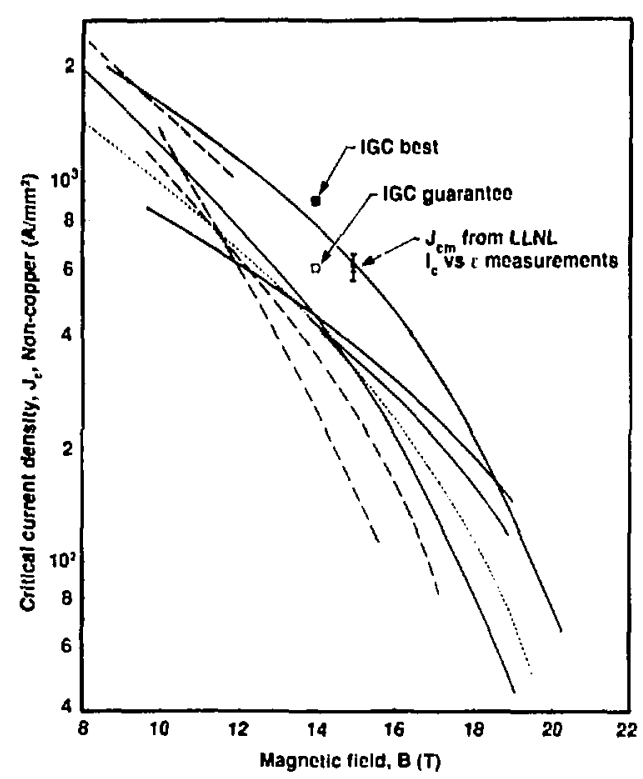

Figure 1: Critical current in $\mathrm{N}_{\mathrm{b}} \mathrm{Sn}$.

Table II: Properties at $4.2 \mathrm{~K}$ of cryogenic stcels.

\begin{tabular}{|c|c|c|c|c|}
\hline Material & $\begin{array}{l}\text { Yield } \\
\text { stress } \\
\text { (MPa) } \\
\end{array}$ & $\begin{array}{l}\text { Litimate } \\
\text { stress } \\
\text { (MPa) }\end{array}$ & $\begin{array}{l}\text { Fracture } \\
\text { toughness } \\
(\mathrm{MPa} \sqrt{\mathrm{m}})\end{array}$ & $\begin{array}{c}\text { Design stress } \\
\text { (MPa) }\end{array}$ \\
\hline C StS-JWI & 1250 & 1650 & $200^{-1}$ & $\overline{825}$ \\
\hline C SLS-JKAI & 1200 & 1650 & 210 & 800 \\
\hline $02 \times 20 \mathrm{H} 16 \mathrm{~A} 6$ & 1326 & 1834 & 180 & 700 \\
\hline $03 \times 13 \mathrm{Hg} 19 \mathrm{AM}$ & 1530 & 2000 & $\ldots$ & 750 \\
\hline
\end{tabular}

Table III: Properties of candidate materials for conductor conduit to be heat-treated at about $700^{\circ} \mathrm{C}$

\begin{tabular}{|c|c|c|c|}
\hline Material & $\begin{array}{l}\text { Mouiulus } \\
\text { (GPa) }\end{array}$ & $\begin{array}{l}\text { Yield } \\
\text { stress } \\
\text { (MPa) }\end{array}$ & $\begin{array}{c}\text { Titimate } \\
\text { stress } \\
\text { (MPa) }\end{array}$ \\
\hline$\overline{\mathrm{JE}}-75$ & 207 & 1250 & $\frac{1750}{}$ \\
\hline A286 & 207 & similar & similar \\
\hline Incoloy 908 & 180 & similar & similar \\
\hline
\end{tabular}

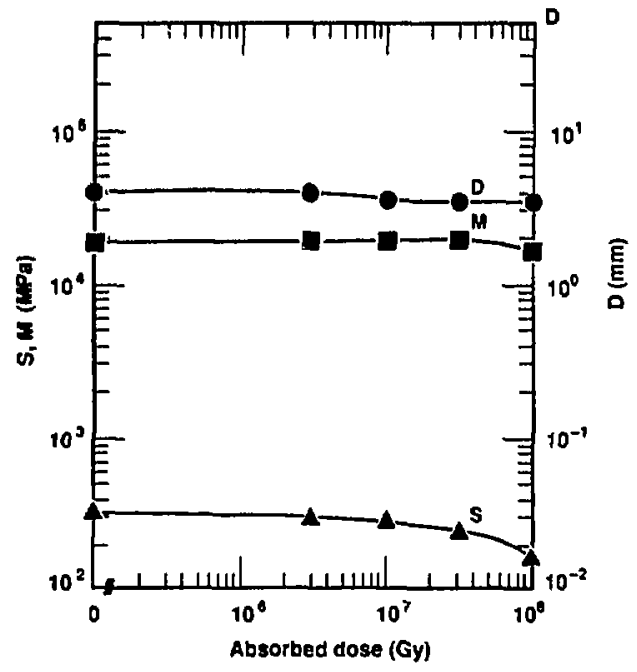

Materlal:

Solventiess epoxy resin No. 332. Base DGEBA MNA other components relniorced with flber-pllanized glase-cloth becking (type 3)

Type:

Orlltherm-D Insulatlon

Supplier:

BBC Baden

Remarks:

Magnet coll Insulation application

Curve property

Initial value

S Flexural strength

$324.0 \mathrm{MPa}$

at maximum load

$4.2 \mathrm{~mm}$

D Deflectlon at maximum load

M Modulus of elasticity

$19,240.0 \mathrm{MPa}$

RI Radiatlon Index $\left(10^{5} \mathrm{G} / \mathrm{h}\right)$

8.0

Figure 2: Radiation darnage to * poxy-ylass. 

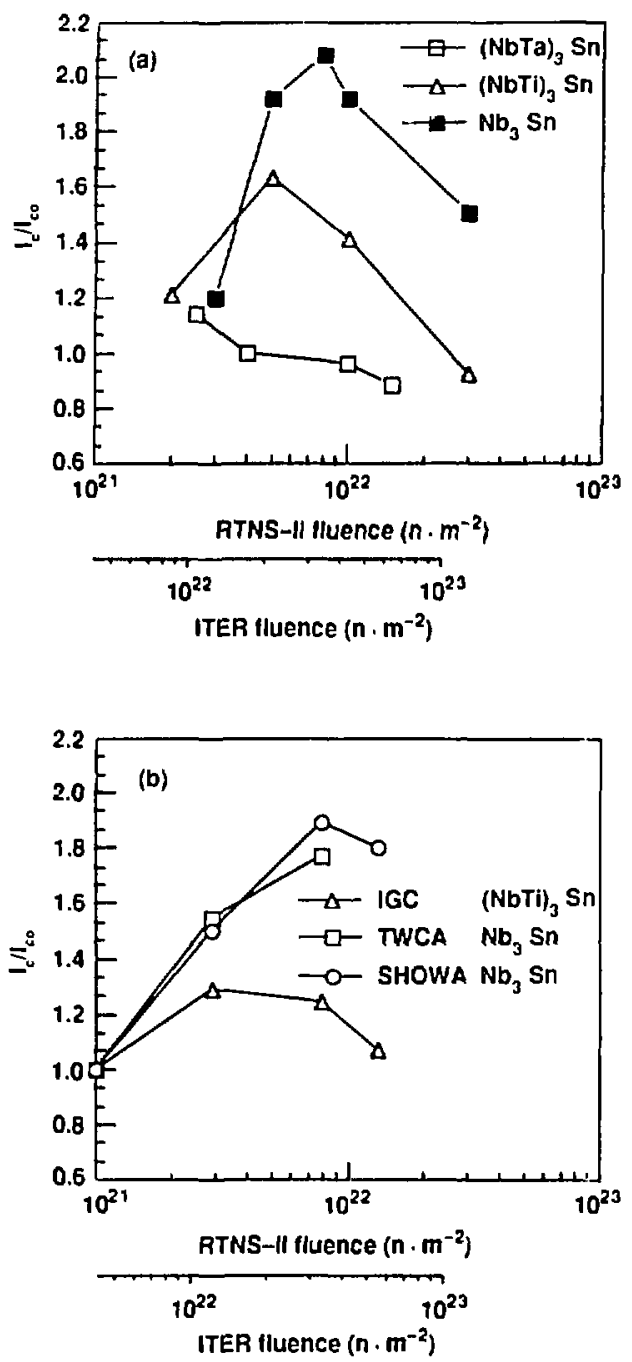

Figure 3. Damage to superconductars.

\section{Rosearch and Development}

The design effurt ti, II EH is accompanted by a signicant magnet $\mathrm{K} \& \mathrm{D}$ effort as summarized in Table $Y$ This is needed because a large ignited/buming plasma as in ITEK will require higher steadystate magnetic ficlds than previously achjeved TF roils of $12 \mathrm{~T}$ and large size requirc holi-current nuobum-tin superconductors to operate under condituons of hugh stress, cyclic loading, and nuclear heating. Jgnition places large demands on the poloidal coil syistem becausc a large amount of energy is requared to starl up ind burn the plasma Accordingly, the conductors must cperiste ness t/1 k A and about $12 T$ or grenler in the centrnd solenotd

If the TF ningnets call be made more radiation tolerevit, the neutron shjelding may be reduced to permut a smaller lokamak or conversely a larger, higher current plasmi to achieve gention Insu. lators such as polyimules, or advanced epoxy-gloss with forcid-flow conductors, sitpinble of high neutron hent remowibl and gered st nlsility even with ratuntion-diunnged eopper stabilizers, are being oluthed to sere if this gead crus be neluevel of course, large cryogenie compo-

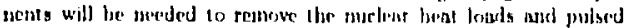
ficld lesses:

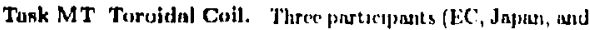
LSSR) alfered to contribute "T'F conduct or development, and the Li.S. plans to develop TF conductor concepts though an integrated pro. gram comphasizing radiation-tolerant niagnets Three conecpts have been proposed react rand-wind by the EC. LSSK, and Japan; wind. and-rcact by the $\mathrm{C}: S$ : and the preformed armor technique discussed by Japan-- an interneduate visiant that allows specin high-strength stcels to be arlded as distribusied structure to the conducior after reaction Development of these different concepts provides options that would be lost if only one course were pursued. The cost of devel. opment of such pre-prototypienl conductor inodels is small compared to the quantity and quality of informntion that ean be obtained by fabricating and testing them.

Although ald the teans have proposed developing and testing fult-scale TF conductors, no participant possesses a test facility of sufficient size and ficld strengeh. The requirements for such test facilities (useful also for testing developmental PF conductors) can be roughly described as follow:s: high, transverse ficld exposure of at least 0.3 to $0.4 \mathrm{~m}$ of conciuctor (the conductor must be meters in length to allow jounts outside the high-ficld region) to magnetic

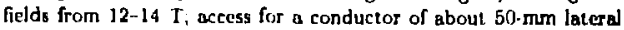
dimension; and application of current of about $40 \mathrm{kA}$. Critical current at the designed uperating field and current can be determined by raising the temperat ure. Suzzestions for such a lest facility are being examined

Takk MP Poloidal Coil. Development of conductors appropriate for the PF central solenold has been proposed directly by the $\mathrm{EC}$, in generic fashion by the l'.S., and as part of a PF coil devel. opment by Japan Both the LS. and the EC (with vocal support from the USSR) favor wind-and-react, cable-in-conduit approaches to PF central solenoid fabrication and have chosen their conductor development paths accordingly. The approaches of these teams differ, however, in the fabrication techniques being investigated.

Table IV: Tentative parameters for ITER.

\begin{tabular}{ll} 
Major radius & $5.8 \mathrm{~m}$ \\
Minor radius & $2.0 \mathrm{~m}$ \\
TF on axis/at conductor & $5.1 / 11.3 \mathrm{~T}$ \\
Plasma current & $20 \mathrm{MA}$ \\
Fusion power & $1 \mathrm{GW}$ \\
Outer radius of central solenold & $2 \mathrm{~m}$ \\
Thickness of inboard TF coil region & $0.75 \mathrm{~m}$ \\
Thermal isolation thickness & $0.05 \mathrm{~m}$ \\
Shield/frst-wall region thickness & $0.8 / 0.85 \mathrm{~m}$ \\
\hline
\end{tabular}

Table " Participants in ITER magenet R\&D.

\begin{tabular}{|c|c|c|c|c|c|}
\hline & Task & $E C$ & U.S & Japan & USSR \\
\hline $\mathrm{MT}$ & Toraidal coil & $\bar{x}$ & & $\mathrm{x}$ & $x$ \\
\hline MP & Poloidal coil & $\mathrm{x}$ & & $\mathrm{x}$ & \\
\hline MI & Insulation material & $\mathrm{x}$ & $\mathrm{x}$ & & $\mathrm{x}$ \\
\hline MS & Magnet structure matenal & $\mathrm{x}$ & & $\mathrm{x}$ & \\
\hline MA & Fiadration-tolcrant magnets & & $x$ & & \\
\hline$M C$ & Cryogenics & & $x$ & $x$ & \\
\hline
\end{tabular}


The Japanese preformed armor conductor, sometimes proposed by them as an PF central solenoid conductor candidate, offets alternatives for fabrication techriques and materials. Japan has been fabricating a coil (DPC-TJ) using this preformed armor cable-in. conduit conductor. The DPC-TJ is not a pulsed coil; houever, it will verify the production feasibility of this new roncept and mechanical advartages.

The PF central solenord will be an extension of the state of the ast; thereforc, paniciparts were encouraged to tnodify their development of plans to include the ITER PF central solenoid requirements (magnetic fields of $12 \mathrm{~T}$ and higher, currents near $40 \mathrm{kA}$, and ranp rates of about $1 \mathrm{~T} / \mathrm{s}$ ).

Task MI-Insulation Material. All participants have pro posed work in irradiating and testing the negmet instalations. The U.S plans to extend the testing to higher exposures (10 $10^{10}$ rad) and to oystems that do not rely on shear louding. Some studies undicate that the insulation kystertus proussud by the EC, will toleratc higher exposures thin the $6 \times 10^{6}$ rads plasued for their tests

Tusk MS-Mngutet Structure Materin). Jis magnel cascs, the Jвралеse and the USSR tenus have einphasized developitig cryo. genie stcels with dramatically improved properties. J'articularly in Japiul, reliable cryogeric stexls (JCS) have been developed and are commercially avajlable.

Task MA--Radiation-Tulerant Magnets. The U.S has proposed an overall reduction in maclune size and costs by simultaneously eleva:ing ilie reliable performance levels of the superconduct Ing magret systems and designing them to accept highor radiation exposure. This integrated approach is one that both feeds and is fed by the developments of individual magnet system components, such as conductors, cryogenic components, insulation systems, and structural materials. The U.S. Leam believes this developinent approach is essential to significantly improve performance in these theas.
Task MC Cryogenics. The cryogenc system of ITER must nbsorb ipproximately $10 \mathrm{~kW}$ at $4.5 \mathrm{~K}$, corresponding to power consumption from the grid of several tons of MW: Japan and the L'SSR propose cumplementary appronches the CSSR emphasizing devel. opment of the laggest components such in rompressors, and Japan choosing to develop more sophisticated components such as turbo expanders and lolium pumps

\section{Conclusion}

The ITF.H collitionatson hins niready produced some convergence in magenct clesign ariteria and a colsesive plan for RKD work. The definition phise will be completed in 1988 'The design phase will continue thruugh 1991. when the conceptual design report will br innde.

\section{neformest}

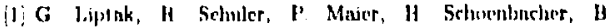
Hnberlbure, II. Museller, and W Zeier, Radiation Tests on SeIncted Electrital Insulating Baternals for /hgh-l'ower and High. Voleage Applicution, CERS report B5-02, Gencra, Swit aerland (March 1985)

(2) R. Flucker, W Maurer, F. Wciss, Hahn, and M. Gilinan, IEEE Thuns Magn MAG-23, 976 (j987).

[3] M Guinan, H. Hahn, and T. Okada, Studies of Supcnconductors atut Stabuluars for Fusion Magnets, Lawrence Livermore National l,aboratory, Livermore, CA, UCID-21298 (1988) 